DOI

\title{
ПОРУШЕННЯ ІМУННОГО ГОМЕОСТАЗУ В РАННІЙ ПЕРІОД РОЗВИТКУ ЕКСПЕРИМЕНТАЛЬНОї ПНЕВМОНІї
}

\author{
○С. М. Регеда, Л. О. Фурдичко, М. М. Регеда-Фурдичко \\ Львівський національний медичний університет імені Данила Галицького
}

\begin{abstract}
РЕЗЮМЕ. В експерименті на морських свинках показано, що пневмонія супроводжується порушеннями показників імунної системи, які проявлялися поступовим зростанням вмісту В-лімфоцитів і циркулюючих імунних комплексів (ЦІК) на 4-у і 8-у доби на тлі зниження рівня Т-лімфоцитів у крові на 8-у добу розвитку запального процесу в легенях.

КЛЮчОВІ СЛОВА: експериментальна пневмонія, циркулюючі імунні комплекси, Т і В-лімфоцити.
\end{abstract}

Вступ. Хвороби органів дихання займають значну питому вагу в клініці внутрішніх хвороб, серед яких пневмонія посідає одне з перших місць. Не дивлячись на великі успіхи розвитку медицини та фармації у практичній роботі лікаря спостерігаються випадки неправильної діагностики та неадекватного лікування хворих на цю патологію [1, 2].

3 одного боку діагностика пневмонії $\epsilon$ нескладною за умови класичного клінічного перебігу захворювання та застосування основних та додаткових методів обстеження, з іншого - ця патологія може перебігати з атиповою клінічною симптоматикою, тому спостерігаються випадки гіпер- або гіподіагностики. Останнє зумовлює розвиток ускладнень і такі хворі можуть потрапляти в реанімаційне відділення лікарні. Власне у хворих з ускладненою пневмонією виявляються періоди непрацездатності та смертність. Тому пневмонія набула медичного та соціально-економічного значення $[1,2]$. На сьогодні патогенез пневмонії залишається невивченим, зокрема не повністю встановлені роль і значення імунних процесів у формування цієї патології. Відомо, що у хворих на пневмонію порушується імунний статус, проте не повністю досліджено зміни усіх імунних аспектів у динаміці розвитку пневмонії. Тому метою нашого дослідження було вивчення особливостей порушень клітинного та гуморального імунітету за умов розвитку раннього періоду пневмонії.

Матеріал і методи дослідження. Експериментальні дослідження проводили на 39 морських свинках - самцях масою 0,18-0,21 кг. Морські свинки були поділені на три групи:

- перша група - інтактні тварини (контроль) (15 тварин);

- друга група - морські свинки з експериментальною пневмонією на 4-у добу (12 тварин);

- третя група - морські свинки з експериментальною пневмонією (ЕП) на 8-у добу (12 тварин).

3 літератури відомо, що будь-який запальний процес перебігає у вигляді наступних стадій: інку- баційний період, продром і розпал хвороби (розвиток, розгорнута картина, криза і завершення клінічних проявів) $[1,2]$. Отже ранній період у нашій роботі відповідає розвитку та кризи ЕП.

Для інтерпретації одержаних даних та їх подання умовно виділяли два періоди: ранній-морські свинки на 4-ту і 8-у доби розвитку ЕП, пізній тварини з ЕП після 10 діб.

Експериментальну пневмонію відтворювали за методом В. Н. Шляпникова, Т. Л. Солодової, А. С. Степанової [3].

Згодом морських свинок декапітували під ефірним наркозом на 4-у та 8-у доби формування запального процесу в легенях, і у інтактних тварин та забирали легені для біохімічних досліджень.

Визначали вміст Т і В лімфоцитів (СД і С в крові за методом Е. Ф. Чернушенко, Л. С. Когосова [4]. Рівень циркулюючих імунних комплексів (ЦІК) в крові за методом V. Haskova, J. Kaslik [5].

Отримані цифрові результати досліджень опрацювали статистичним методом за Стьюдентом.

Результати й обговорення. Результати імунних досліджень показали, що в ранній період, який охоплює 4-у і 8-у доби розвитку експериментальної пневмонії, відбуваються помітні зміни окремих маркерів клітинного та гуморального імунітету.

Так, на 4-у добу формування ЕП не виявлено достовірних порушень вмісту Т-лімфоцитів у крові, який не відрізнявся від фізіологічних констант. Далі, на 8-у добу цієї експериментальної моделі хвороби, було показано зниження рівня Т-лімфоцитів у крові на $38,4 \%(P<0,05)$ проти першої групи морських свинок, що свідчить про пригнічення клітинної ланки імунітету (рис. 2).

Оцінювали стан гуморального імунітету при ЕП за визначенням вмісту В-лімфоцитів та ЦІК у крові.

Нами встановлено, що на 4-у добу розвитку ЕП відбувалося підвищення рівня В-лімфоцитів у крові на 19,8 \% (Р<0,05) відносно контролю. Згодом, на 8-у добу експерименту, спостерігалося 
Огляди літератури, оригінальні дослідження, погляд на проблему

подальше зростання вмісту В-лімфоцитів у крові на $47,9 \%(P<0,05)$ при порівнянні з інтактною групою тварин.
Одержані результати вказують на стимуляцію гуморального імунітету за умов розвитку ЕП (рис. 1).

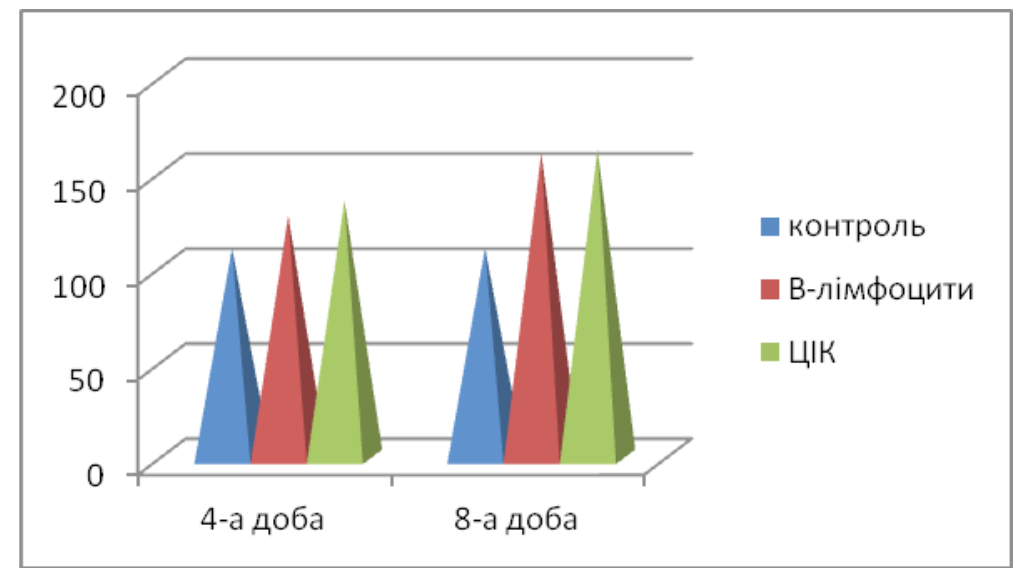

Рис. 1. Вміст окремих показників гуморального імунітету у ранній період розвитку ЕП (\% від контролю).

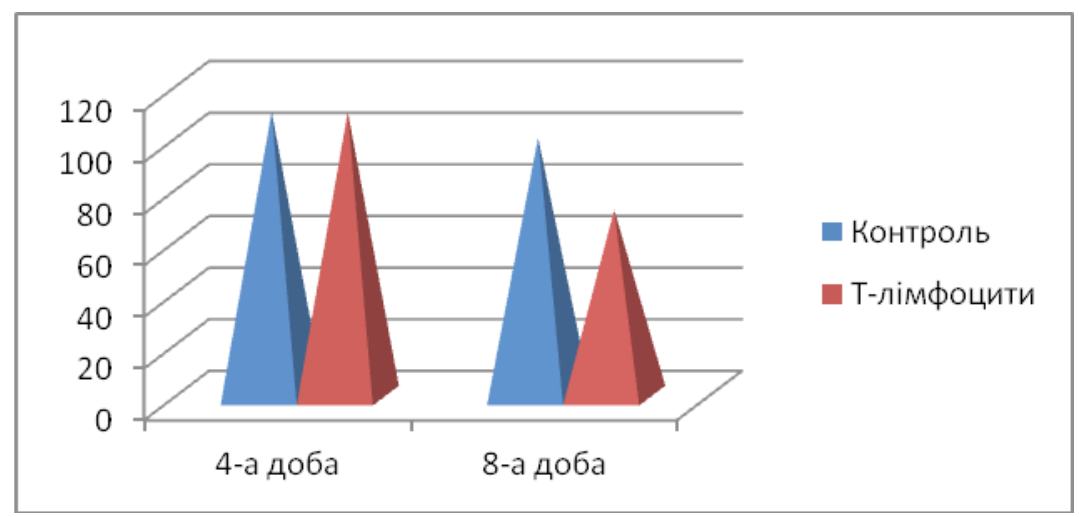

Рис. 2. Вміст Т-лімфоцитів у крові в ранній період ЕП (\% від контролю).

Важливе значення для характеристики імуннокомплексного механізму пошкодження клітин має визначення рівня ЦІК в крові при ЕП.

Нами виявлено, що на 4-у добу розвитку ЕП відбувалося зростання вмісту ЦІК в крові на 25,8 \% $(P<0,05)$ проти контролю. Пізніше на 8-у добу цієї експериментальної моделі хвороби спостерігалося подальше підвищення рівня ЦІК у крові на $50,8 \%(P<0,05)$ відносно першої групи тварин, що свідчить про активізацію імунних процесів за умов розвитку ЕП (рис. 1).

Таким чином, проведені імунологічні дослідження окремих показників імунної системи на 4-у і 8-у доби експерименту показали підвищення вмісту СД19 і ЦІК та зниження рівня СДЗ у крові, що свідчить про порушення імунного гомеостазу в ранній період формування ЕП.

Висновки. 1. Експериментальна пневмонія супроводжується стимуляцією гуморальної ланки імунітету, що виражається зростанням рівня СД ${ }_{19}$ та ЦІК у крові як на 4-у так і особливо на 8-у добу експерименту.

Ранній період 4-а доба формування експериментальної пневмонії не вплинув на вміст СД $у$ крові, даний показник знаходився на рівні контрольних величин, водночас на 8-у добу експерименту спостерігалося його зниження.

\section{ЛІТЕРАТУРА}

1. Регеда М. С. Пневмонія: монографія / М. С. Регеда, М. М. Регеда, Л. О. Фурдичко // вид. 6-те доп. та переро6. - Львів, 2012. - С. 162.

2. Запалення типовий патологічний процес / М. С. Регеда, Т. М. Бойчук, Ю. І. Бондаренко, М. М. Регеда // вид. 2-ге доп. та перероб. - Львів, 2013. - С. 149. 
Огляди літератури, оригінальні дослідження, погляд на проблему

3. Экспериментальные модели острых пневмоний, вызванных условно-патологическими бактериями и их ассоциацией: метод. указания / сост.: В. Н. Шляпников, Т. л. Солодова [и др.] // Саратов, 1998. - 30 с.

4. Чернушенко Е. Ф. Иммунология и иммунопатология заболеваний легких / Е. Ф. Чернушенко, Л. С. Когосова. - К. : Здоров'я, 1981. - 208 с.
5. Haskova V. Novy zpusob stanoveni circulujicich imunokomplexy w lidskych serech / V. Haskova, J. Kaslik, M. Matejckava // Cas. Lek. Ces. - 1977. - T. 116, № 14. S. 436-437.

\section{VIOLATION OF IMMUNNO EXPERIMENTAL HOMEOSTASIS IN THE EARLY STAGES OF DEVELOPMENT OF EXPERIMENTAL PNEUMONIA}

\section{@S. M. Reheda, L. O. Furdychko, M. M. Reheda-Furdychko}

Lviv National Medical University by Danylo Halytskyi

SUMMARY. In the work shown that in the fourth and eighth day the formative experimental pneumonia (EP) happening on the background gradual increase of content B-lymphocytes and circulatory immune complexes (CIK) on 4th and 8th day reduction level gradual increase of T-lymphocytes in the blood on 8th day of the development of inflammatory prosess in lungs.

KEY WORDS: experimental pneumonia, circulatory immune complexes, T- and B-lymphocytes.

Отримано 23.10.2015 